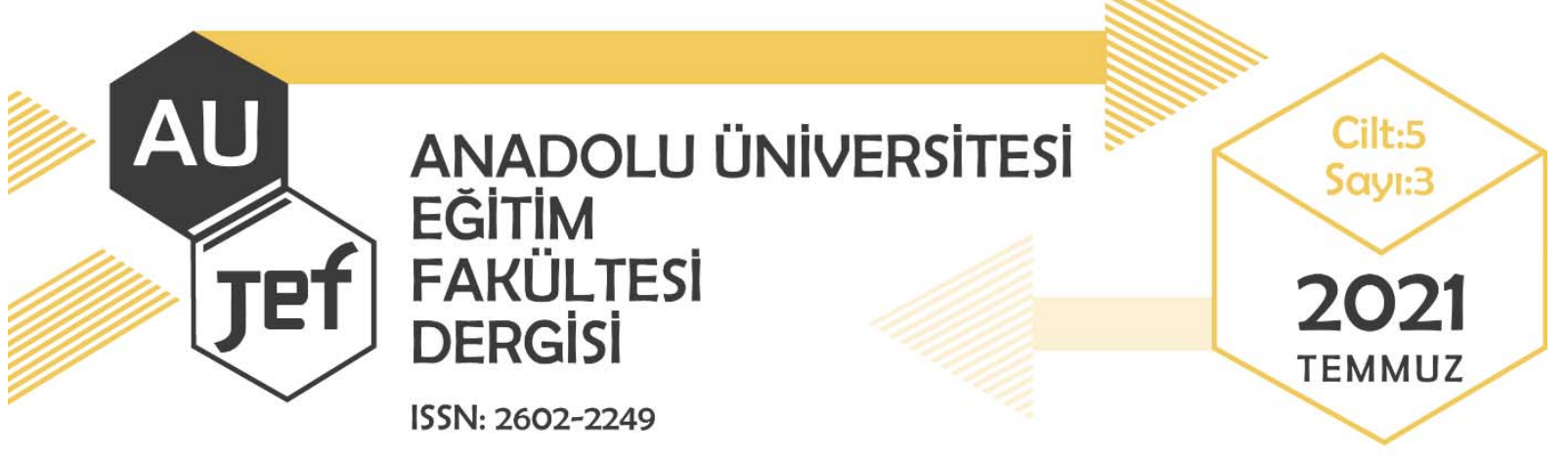

\title{
Liberalizmin Öğretim Programına ve Eğitimin Yönetimine Etkileri Üzerine Bir Araştırma
}

\section{A Study on the Effects of Liberalism on the Curriculum and Education Management}

Turan Akman ERKILIÇ ${ }^{1}$

Makale Türü: Araştırma Makalesi

Başvuru Tarihi: 25.02.2021

Kabul Tarihi: 17.06.2021

Atıf İçin: Erkılıç, T. A. (2021). Liberalizmin öğretim programına ve eğitimin yönetimine etkileri üzerine bir araştırma. Anadolu Üniversitesi Eğitim Fakültesi Dergisi (AUJEF), 5(3), 246-263.

ÖZ: Bu çalışmanın temel amacı liberalizmin öğretim ve eğitimin yönetimine etkilerini belirlemek ve tartışmaktır. Temel amaca bağlı olarak liberalizmin öğretimin programının ögelerine amaç, içerik-konu, öğretme ve öğrenme süreçleri ile ölçme değerlendirme boyutlarındaki etkilerinin neler olduğu ve öğretim programlarını nasıl etkilediği ile bir toplumsal kurum olarak eğitimin yönetimine kurumsal yönetim ile ekonomi-politik boyutlardaki etkileri ve yansımaları araştırılmışıır. Çalışma, bütünleştirilmiş alanyazın taramasına dayalı alan incelemesi türünde bir araştırmadır. Çalışmada liberalizm ve eğitime etkileri sorunu analiz, sentez ve sonuçlar bağlamında değerlendirilmiş ve önerilere yer verilmiştir. Liberalizme göre eğitim sistemlerinin amacı özgür ve ekonomik bireyi yetiştirmektir. Programların içeriğinde özgürlükçülük ve çok yönlülük egemen olmalıdır. Öğretme ve öğrenme süreçlerinde görecelik ve duruma uygunluk olmalıdır. Ölçmede ise bireysel hak ve özgürlüklerin bilincinde etkili, verimli, bağımsız ve bireyin yaşama hazırlıklı olup olmadığı ölçülmelidir. Liberalizmin eğitim kurumlarının yönetimi boyutlu etkileri merkezden yönetim yerine yerelden yönetim, öğrenen ve velinin yönetime katılması, küreselleşme kuralsızlaştırma, toplam kalite yönetimi ve akademik ve yönetsel özerklik biçiminde belirlenmiștir. Liberalizmin eğitime ekonomi-politik boyutlu etki ve yansımaları; eğitimde özelleştirme, eğitim hizmetlerinden yararlananların eğitime mali katkısı, eğitimin piyasalaştırılması, eğitimin dışallık argümanlarının zayıflatılması imajıdır. Liberalizmin eğitim alanına etkileri alan uzmanlarına sorularak nicel ve nitel araştırmalar yapılabilir. Ayrıca diğer sosyoekonomik politik yaklaşımların eğitime etkilerini karşılaştıran araştırmalar yapılabilir.

Anahtar sözcükler: Eğitim yönetimi, felsefe, liberalizm, neo-liberalizm, öğretim programının yönetimi.

\begin{abstract}
The main purpose of this study is to identify and discuss the effects of liberalism on the management of education and training. Based on the main purpose, the effects of liberalism in the dimensions of purpose, content-subject, teaching and learning processes, assessment and evaluation, which are components of education curriculum, and how it affects the curriculum, as well as the effects and reflections on the management of education as a social institution in institutional management and economic-political dimensions have been investigated. The study is a literature review based on integrated and focused literature review. In the study, the problem of liberalism and its effects on education, analysis, synthesis and results are evaluated and suggestions are included. According
\end{abstract}

\footnotetext{
${ }^{1}$ Doç. Dr. Anadolu Üniversitesi Eğitim Fakültesi, terkilic@anadolu.edu.tr, Orcid: 0000000225072663
} 
to liberalism, the purpose of education systems is to raise a free and economic individual. Liberalism and versatility must be dominant in the content of their programs. Relativity and appropriateness must be integrated in the teaching and learning processes. As for evaluation, it should be assessed that whether or not the individual is effective, efficient, and independent and prepared for life and has the awareness of individual rights and freedoms. The effects of liberalism on the management of educational institutions are determined as local instead of centralized management, participation of learners and parents in management, globalization, deregulation, total quality management, and academic and administrative autonomy. The effects and reflections of liberalism on education in terms of economy and politics can be summarized as privatization education services, the financial contribution of the beneficiaries to the education, marketization of education and the image of undermining the externality arguments of education. Quantitative and qualitative studies can be conducted by asking experts in the field the effects of liberalism on education. Besides, the studies comparing the effects of liberalism with the effects of other socio-economic political approaches can be performed.

Key words: Liberalism, neo-liberalism, philosophy, management of curriculum, educational management. 


\section{GíRiş}

Bir sosyoekonomik ve politik yaklaşım olarak liberalizm yüzyıllardır ülkelerin sosyal, ekonomik, politik ve eğitim süreçlerinde etkili olmaktadır. Yayla'ya (2008) göre liberalizm, etimolojik olarak “özgürlük” karşılığında kullanılmakla birlikte günlük dilde farklı anlamlarda kullanılmaktadır. Liberalizmin doğrudan bir felsefe olup olmadığı tartışmalı olsa da felsefenin hayata tavır alış olduğu noktasında liberalizm ağırlıklı olarak politik ve ekonomi odaklı bir felsefi anlayış olarak kabul edilebilir. Liberalizm özünde birbirinden soyutlanmayan bir ekonomik sistem, politik yönetim karş1lıkları yanında bir sosyal yaşam karşıllı̆̆ da taşımakta; bu yönüyle liberalizm demokratik yönetim biçimi olarak kabul görmektedir (Çetin, 2001). Özetle liberalizm din, inanç ve düşüncede özgürlüğü politik değer olarak kabullenen bir düşünce akımı ve piyasa ekonomisini temel alan ekonomik-politik bir yaklaşımdır. $\mathrm{Bu}$ bağlamda bir araştırma konusu olarak liberalizmin düşünsel olarak ekonomik, politik ve felsefi nitelikleriyle ele alınması bir gerekliliktir.

Bir siyasal yaklaşım olarak liberalizmin temel nitelikleri şu başlıklar altında toplanabilir: Tarihsel olarak geçmişi daha öncelere gitse de çağdaş anlamda liberalizm on dokuzuncu yüzyıl ideolojisidir. Liberal ideoloji çok fazla ekonomik sorunları olmadığı için ruhban, aristokrat sınıf ile yasa önünde eşitlik isteyen yeni burjuvazinin ideolojisi olarak tanımlanır (Öztekin, 2018). Liberalizm, liberal devlet anlayışı ile tüm yurttaşlara karşı eşit uzaklık anlayışı ile "kör devlet" anlayışındadır. Devletin kalkış noktası bireydir ve tek gerçek değer bireydir. Birey toplumdan ve devletten öncedir. Birey toplumun kalbine yerleştirilir ve sosyal düzenin oluşması için merkeze alınır. Toplum bireye tüm potansiyelini gerçekleştirebilmesi için elden geldiğince özgürlükler vermelidir. Özgürlük, akıl ve irade bağımsızlı̆̆ temeldir. Liberalizmin temel nitelikleri bireycilik, özgürlük, akıl, eşitlik hoşgörü, rıza, sınırlı devlet ve hükümet biçimindedir (Cau, 2009).

Siyasal liberalizm bağlamında irdelenmesi gereken bir başka boyut demokrasi ve liberalizmdir. Liberal demokraside klasik demokrasilerdeki gibi hem dolaylı katılım hem de doğrudan katılım söz konusudur. Seçimlerin yarışmacı niteliği ve halk istem ve dilekleri ile sorunlara çözüm seçeneklerinin oluşturulması ve tercihlerin uygulanması olanağı bulunur. Ayrıca toplanma ve örgütlenme özgürlükleri, sivil toplum örgütleri, medya ve işçi işveren kuruluşları aracılığıyla kamusal sorunlara yönelik siyaset kurumlarına etkide bulunurlar (Şahin, 2018). Liberal demokrasi bir bakıma meşruiyetini halkın rızasından ve insan haklarına saygıdan alan fakat sınırsız yetki sahibi olmayan, sinırlı ve anayasal bir yönetimdir (Erdoğan, 2003). Liberal görüş ağırlıklı olarak yerelleşme ve yerel demokrasiyi savunur. Yerel siyasal katılımın, yerel özgürlüğün ve yerel demokrasinin yerel yönetimlere yetki devredilerek gerçekleştirilebileceği düşüncesindedirler. Yerel demokrasinin etkin olarak işleyebilmesi için yerel yönetimlere önemli bir sorumluluk yüklenmelidir. Halka yakın birimler olması sebebiyle yerel yönetimler, halkın istek ve düşüncelerini iletilebildiği, yönetimin yapmış olduğu faaliyetlerden doğrudan haberdar olabildiği önemli demokratik mekanizmalardır (Çelik ve Usta, 2011). Liberal anlayış özünde tüm insanların din ve vicdan özgürlüğünü savunur. Bu noktada üçüncü tarafların baskı ve müdahalesi olmadan bireyin bilinç ve vicdan değerlendirmesine göre bir dine, değere ya da ahlâka inanması ya da inanmamasını içerir. Özetle din özgürlüğü, toplumda yaygın olarak inanılan din ve inançların özgürlüğü değil; herkesin din ve inanç özgürlüğüdür (Sambur, 2011).

Liberalizm siyasal boyutuyla şu nitelikleri taşır: Liberalizmde bireylerin ifade özgürlüğüne sahip olması temeldir. Din, devlet ve hükümet gibi kimi kurumların gücünün sinırlı olması temel alınır. Düşüncenin serbest bir şekilde dolaştığı, özel teşebbüse olanak sağlayan bir serbest piyasa ekonomisi temeldir. Hukukun üstünlügünü geçerli kılan şeffaf bir devlet modeli ve toplumsal hayat düzen esastır. Liberal devlet anlayışı, her toplumun bir düzene gereksinimi olduğu ve bu düzenin yansız bir kişi

Anadolu Üniversitesi Ĕ̆itim Fakültesi Dergisi (AUJEF), 5(3), 246-263 
(hakem) tarafından çözülmesi gerektiği anlayışına dayanır (Tanilli, 2007). Bu bağlamda politik açıdan liberalimin kimi nitelikleri temel hak ve özgürlükler, din devlet ayrıklığ 1 yani laiklik, devletin tüm kişi ve kuruluşlara eşit uzaklıkta olması, parlamento ve halkın temsili ve sınırlı hükümet şeklinde sıralanabilir (Ralph, 2011; Aktan, 1995).

Bir ekonomik model veya yaklaşım olarak liberalizmin nitelikleri şu ilkelere dayanır: Ekonomik işleyiş serbest piyasa ilkelerine dayanmalıdır. Devletin mal ve hizmetlerin üretilmesi ve tüketilmesinde bir görevi olmamalıdır. Ekonomide özel sektör ve birey asıl itici güçtür. Devletin büyümesi esaretin büyümesine neden olur ve olumsuzluklar yaratır. Piyasada doğal olarak oluşan kaynakların devlet eliyle "ahlaki değerler", "sosyal adalet" ve "refah devleti" gibi gerekçelerle dağıtılması gereksizdir (Hayek, 1995). Özel mülkiyet esastır; mülkiyet hakkı kutsal, dokunulmaz bir haktır (Göze, 2016). Devlet için birey yerine birey için devlet anlayışı savunulur. Liberal ekonomi, politik bir sistem olarak demokrasi ile var olabilir. Bir ekonomik sistem olarak liberalizm takas ile alışverişin gönüllülük esasına göre yapıldığı, mülkiyet hakkının teminat altına alındığı bir yapıdır; özetle özel mülkiyet kutsaldır ve bir insan hakkıdır (Holcombe, 1994). Genel olarak ulusal kalkınma; ekonomik, siyasal ve sosyal alanda sağlanan gelişmeler olarak tanımlanmakta ve gelişmemiş toplumların bireyleri bağımlılıktan kurtulmalıdır. Liberasyon teorisinin öncüllerine göre de eğitim yoluyla toplumlar hegemonyayı kaldırıp ulusal gelişimi sağlarlar (Erdoğan İ, 2001). Bu özelliği ile liberal hareket bir bakıma özgürlükçü nitelik taşır. Liberalizm, ekonomik gelişimi özgürlüklere bağlamıştır. Bu bağlamda girişim, ticaret, göç, rekabet, üretim ve tüketimde tercih, iş birliği ve ittifak yapma ekonomik özgürlüklerdir (Ar1 ve Tan, 2018). Ekonomik bir sistem olarak liberalizm özel mülkiyet, rekabet, miras, serbest girişim, fiyat mekanizması ilkelerine dayalı temel ekonomik hak ve özgürlüklerin benimsenmesi esasına dayanır (Aktan, 1995).

Liberalizmin bir felsefi yaklaşım olup olmadığı tartışmalıdır. Bir bakıma "siyasi”" sıfatı, bir öğreti veya ideolojinin kapsayıcı bir felsefi sistem oluşturmadığına fakat sadece devlet-toplum ilişkisi hakkında birtakım normatif önermelerden meydana geldiğine işaret eder. Oysa kapsayıcı bir felsefi sistem temel olarak ontoloji, epistemoloji, etik, estetik gibi bağlamlarda temellendirmeler yapar. Konu boyutuyla siyaset felsefesi konusu olmakla birlikte liberalizmi bütüncül bir felsefe olarak yorumlayan liberaller de vardır (Erdoğan, 2018). Bu noktada liberalizm ontolojik olarak bireyin varlığ 1 ve biricikliği üzerine kurgulanmış bir yaklaşımdır, denilebilir. Bir düşünce ve felsefi akım olarak liberalizmin temel nitelikleri şu biçimde özetlenebilir: Ontolojik açıdan liberalizm, temel olarak özgürlükleri merkeze alan bir anlayıştır. Bireyin hak ve özgürlüklerinin nihayetinde kamunun yararına, genelin çıkarına sonuçlanacağını ileri sürer. Liberalizm, sınıflar yerine bireylerden oluşan bir toplum görüşünü benimser ve öz olarak liberal felsefe varlığını özgürlüklerin oluşturulması ve geliştirilmesine odaklamıştır. Epistemolojik açıdan liberalizm, bilimsel bilgi savunucusudur. İnsan aklının tek yol gösterici olduğunu kabul eder ve insan aklının sürekli bir şekilde ileriye doğru geliştiği anlayışı sonucu akıl dışı engellerin kaldırılarak akla uygun "rasyonel" bir düzen kurmanın gerekliliğini savunur (Ağaoğulları ve Köker, 1991). Ontolojik olarak bireyi kabullenmekte, epistemolojik olarak rasyonel bilgiyi savunmaktadır (Erdoğan, 2018). Değerler açısından liberal anlayışın dayanağı birey ve özgürlüklerdir. Liberalizm, kendisini bireye dayanarak var kılma ve geliştirme amacını taşır. Bireyi sınırlayan ve gelişmesine engel olan toplum ve devlet baskılarına karşı bireyin tarafını tutar. Bireyi her şeyin temeline oturtması sonucu onun her alanda özgür olmasını sağlamaya çalışır. Aksiyolojik bağlamda liberal anlayış değerlere de bireyi merkeze alarak bakmaktadır. Tüm toplum için geçerli değerler yoktur; değerler bireyler için söz konusudur (Hayek, 1995). Toplumu ve devleti bu alanları sinırlandıran bask1 unsurları olarak değerlendirir. Devlet toplumsal ilişkiler nedeniyle zorunludur; bireyin özgürlüğü başka bireylerin özgürlüğü ile sınırlıdır (Çetin, 2001). Ayrıca bireylerin özgürlüğünü en yüksek amaç olarak belirleyip bu özgürlüğün serbest teşebbüs ve rekabet özgürlüğü, inanç ve ibadet özgürlüğü olarak benimsemektedir 
(Cevizci, 2019). Özetle liberal düşünce akılcılık, özgürlük ve bilimsellik üçlü sacayağına dayanır. Bir ideoloji olarak ele alındığında, liberalizmin ögeleri şu biçimdedir: Bireycilik, özgürlük, akıl, eşitlik, hoşgörü, rıza ve sınırlı hükümet liberalizmin başlıca ögeleridir (Türk, 2003).

Genel bir bakışla liberalizmin türleri farklı gruplarda toplanabilir. Bununla birlikte özellikle neoliberalizm hem uygulama sonuçları hem de güncel olması bakımından dikkate değer görülebilir. Neoliberalizm devletin ekonomiye müdahalesini reddeden ve bunu mümkün olan en az düzeyde tutarak yerine piyasa ekonomisinin etkinlik alanının genişletilmesi üzerinde durur (Yolcu, 2010). Bu bağlamda öncelikle iç pazar, kayıtsız koşulsuz dış pazarlara açılmalıdır. Tüm yönleriyle piyasa ekonomisi ilke ve kurallarının uygulanması amaçlanmalıdır. Özelleştirme ile kamu işletmeciliği alabildiğince azaltılmalı nihai olarak tümüyle sonlandırılmalıdır. Sendikal örgütlenmeler ve demokratik kitle örgütlenmeler zayıflatılmalıdır (Başdemir, 2007). Devletin küçültülmesi, yönetimin yerelleşmesi ve yerel yönetimlerin işlevsel kılınması sağlanmalıdır. Kültürel küreselleşme ile kültürlerin melezleşmesinin önünün açılması, evrimleşme söz konusudur (Aktel, 2001). Neoliberal uygulamalarla büyüme durağanlaşmış, eşitsizlikler artmış ve büyüme olumsuz etkilemiştir (Boratav, 2016). Dış borçların arttığı ve gelişme sürecindeki ülkelerin bağımsızlığını yitirme eğilimi söz konusudur (Yeldan, 2009).

Genel olarak liberalizme yönelik sosyal, ekonomik ve politik bağlamlı olumlu görüşlerin yanında olumsuz görüşler de söz konusudur. Nitekim tarihsel olarak neoliberalizm biçemine bürünen liberal anlayışa yönelik eleştiriler yöneltilmektedir. Özellikle sosyal devletin zayıflatılması, özgürlüklerin kısıtlanarak az gelişmiş ülkelerde otokratik yapıların oluşması eleştirilerin bir kısmıdır. Eğitim, sağlık, sosyal güvenlik politikalarından devletin vazgeçişi ile sosyal hareketliliği engelleyici olması bağlamlarında liberalizme yönelik çok sert eleştiriler yapılmaktadır (Uzunyayla ve Ercan, 2008). Örneğin sağlık alanında şu tespitler yapılmaktadır: Kamu sektörünün bir görevi ve sosyal bir hak olarak tanımladığ1 ve insan hakkı kapsamında gördüğü sağlık hizmetlerinin alınıp satılabilir bir metaya dönüştüğü görüşleri yaygındır. Böylece sağlık hizmetlerine erişimde ekonomik, toplumsal, sınıfsal ve sosyal gibi çok sayıda eşitsizlik gündeme gelmiştir (Turancı ve Bulut, 2016). Nitekim Boratav (2016)'a göre liberalizmin büyümeyi yükseltecek katkıları şüpheli, üstelik eşitsizlikler açıkça artmakta ve eşitsizliklerin artışı büyümeyi de olumsuz etkilemektedir. Liberalizm genel olarak söylem ve istençlik bağlamında olumlu görüşler ifade etse de verili durum "meritrokasi", "volantirizm" ve "kazanılmış statüler" konusunda liberalizmin pratikte savundukları çökecek durumdadır (Gümüş, 2008).

Etkileşim sürecinde liberalizmin eğitim alanına etkisinin olacağı kuşkusuzdur. Nitekim liberalizmin öğretim programının ögeleri olan amaç, içerik-konu, öğretme ve öğrenme süreçleri ile ölçme değerlendirme boyutlarındaki etkilerinin neler olduğuna ve öğretim programlarını nasıl etkilemekte olduğuna ilişkindir. Bu aşamada liberalizmin ilkeleri bakımından eğitimin amaçlarına şu etkilerinin olduğu görülmektedir: Liberalizmin özgürlük ve demokrasi savunuculuğu ilkeleri nedeniyle yetişecek bireyde özgür düşünce sahipliği esastır. Ayrıca demokratik ilkelere sahiplik ve demokratik davranışların edinimi temel amaçlardandır. Liberalizmin temelde kapitalist üretimin ve piyasa ekonomisinin temel alınması (Yayla, 2008) nedeniyle etkili ve verimli birey yetiştirilmesi bir başka amaç olarak öne çıkmaktadır. Liberalizme göre eğitim sistemlerinin amacı "özgür ve ekonomik" bireyi yetiştirmek olmalıdır. Liberal eğitimin genelinde Prens Sabahattin'in "Birey toplum için değil, toplum birey içindir." biçiminde açıkladığı anlayış egemendir. Bu bağlamda bireyci sosyolojinin girişken, kendine yeten, özgür davranan birey yetiştirmeyi amaçladığı açıktır (Tezcan, 2015). Akılcı, bilimsel düşünen, serbest piyasayı kavrayan, temel hak ve özgürlükleri benimseyip içselleştiren birey yetiştirmek liberalizmin kimi amaçlarıdır. Özetle liberalizmin amaçlar boyutundaki etkileri politik ve ekonomik boyutlarıyla iki alt 
başlıkta toplanabilmekte ve temelde demokratik davranışlar ile etkili ve verimli ekonomik bireyin yetiştirilmesi esas alınmaktadır.

Öğretim programı boyutunda içerik bağlamında şu etkiler görülmektedir: Politik liberalizmin etkisi ile okullarda demokratik, özgürlükçü konulara yer verilmesi baskındır. Liberalizm açısından programların içeriğinde özgürlükçülük ve çok yönlülük egemendir. Liberalizm bireyin çok yönlü, özgür, etkili ve verimli olmasını sağlayacak ders ve program içeriklerine yer verilmesini savunur. Liberalizm eğitim sistemleri bireylerin hak ve özgürlüklerini geliştirme, refah artırma ile özgür iletişim olanağ1 ve sosyopolitik denge sağlamayı temel amaçlar olarak belirlemiştir. Öğrenimi engellemek, başkalarının öğrenme hakkını engellemektir. Sağlanması zor olmakla birlikte okullar siyasal ideolojiden uzak tutularak liberal yurttaş yetiştirecek işlevler, değerler, davranışlar, yöntemler yükleyerek bir denge oluşturmalıdır (Kale, 2014).

Öğretim programı boyutunda öğretme öğrenme süreci bağlamında şu etkiler görülmektedir: Liberalizmin eğitim anlayışının ögretme ve ögrenme süreçlerinde görecelik ve duruma uygunluk egemendir. Liberalizmin doğruluk ölçütü olarak "işe yararlılık, etkili, verimli olma ve bireycilik" anlayışlarına göre uygun yöntem ve tekniklerin bulunması serbestîsi açıktır. $\mathrm{Bu}$ bağlamda farklılaştırılmış öğretim, iş birlikli öğrenme, yapılandırmacılık kimi uygulama ve amaçlarıyla liberal anlayışa göreceli uygunlukları olan yaklaşımlardır. Nitekim Prens Sabahattin Türkiye'deki okulları fen ve dil derslerindeki kuramsallık ve öğrencilerin de düşünsel düzey zayıflıkları bakımından eleştirmiştir (Tezcan, 2015). Liberalizm bilimsel bilginin edinimi ve yaygın kullanımını savunur. Liberalizme göre akıl tek yol göstericidir ve insan aklı sürekli ileriye doğru gelişir. Birey ve eğitimin görevi akılcı düşünme yol ve yöntemlerini geliştirmektir (Ağaoğulları ve Köker, 1991).

Öğretim programı boyutunda ölçme ve değerlendirme bağlamında şu etkiler görülmektedir: Eğitim gerek süreç gerek ürün açısından bireysel hak ve özgürlüklerin bilincinde etkili, verimli, bağımsız ve yaşama hazır bireyler halinle gelip gelmedikleri ölçülmelidir. Liberalizmin temel nitelikleri dikkate alındığında objektif testler, işe vuruk ölçme değerlendirme ve ölçme değerlendirme süreçlerinde açıklık, itiraz, hak arama gibi konular öncelik verilmektedir. Bu bağlamdan hareketle yüzyıllardır ülkelerin sosyoekonomik, politik ve yapısal değişimlerine etkisi bulunan liberalizmin eğitime etkilerinin incelenmesi bir sorun alanı olarak belirlenebilir.

\subsection{Araştırmanın Amacı}

Araştırmanın temel amacı liberalizmin öğretim ve eğitimin yönetimine etkilerini belirlemek ve tartışmaktır. Bu temel amaca bağlı olarak aşağıdaki sorulara yanıt aranmıştır.

1. Liberalizmin öğretimin programının ögeleri olan amaç, içerik-konu, öğretme ve öğrenme süreçleri ile ölçme değerlendirme boyutlarındaki etkileri nelerdir ve öğretim programlarını nasil etkilemektedir?

2. Liberalizmin bir toplumsal kurum olarak eğitimin yönetimine, kurumsal yönetim ile ekonomikpolitik boyutlardaki etkileri nelerdir ve toplumsal kurum olarak eğitimi nasıl etkilemektedir, eğitime yansımaları nasıldır? 


\section{YÖNTEM}

$\mathrm{Bu}$ çalışma, alan incelemesine dayalı bir araştırmadır. Alan incelemesi çalışması belirli bir sınırlamaya bağlı ilişkili alanyazını taramaya, sistematik derlemeye dayalı akademik bir süreçtir. $\mathrm{Bu}$ amaçla şu çalışmaların yapılması temel alınır: Uygun alanyazın tarama veya araştırmaları; kaynakların değerlendirilmesi, tartışma konu ve problemin tanımlanması, araştırma yapı ve planının çıkarılması ile bulgulara göre raporun hazırlanması aşamalarını içerir (Rallis, 2018). Alanyazın araştırması alandaki bilgilerin özetlenmesi değil, dokümanlara dayalı konun analizi, sentezi ile eleştirel değerlendirilip soruna ilişkin bir sonucun belirtilmesidir (Galvan, 2006; Merriam, 1988). Bütünleştirilmiş alanyazın taraması (integrative literature review), analiz ve sentezlere dayalı olarak alandaki bilgilerin bütünleştirilmesini amaçlar. Analiz, sentez ve sonuçlara bağlı olarak sorun üzerine öngörü ve önerilerin sürdürülmesi bir gerekliliktir (Torraco, 2005).

Alanyazın incelemeleri, araştırma alanında sistematik derleme metodolojisi olarak da bilinir. $\mathrm{Bu}$ tür araştırmalar birden çok çalışma üzerinde inceleme yapılarak bilgi, bulgu ve sonuçların sentezlerinin yapılmasını amaçlar (Burns ve Grove, 2011). Dokümanlar gözlem veya görüşme yapmaya gerek olmadan bilgiye ulaşmayı olanaklı kılan büyük bir kolaylık olarak nitel araştırmalarda mutlaka dikkate alınması gereken kaynaklardır (Yıldırım ve Şimşek, 2018, s.187). Derleme çalışmaları genel eğilimlerin tanımlanması, geniş çaplı genel çıkarımların yapılması amacı ile teorik tartışma zenginliği ve entelektüel değer taşırlar (Kaşık, 2015).

Araştırma amacına yönelik olarak yararlanılan kaynaklar, felsefe ve yönetim olarak iki ana temada toplanmıştır. Birinci bağlamda "felsefe, felsefeye giriş" adları taşıyan İngilizce ve Türkçe kitap ve akademik makaleler incelemeye alınmıştır. Diğer yandan ikinci bağlamda, yönetim boyutunda, "eğitim, eğitime giriş, eğitim yönetimi, yönetim, yönetime giriş, liberalizm, siyaset bilimi ve siyaset bilimine giriş" ad veya başlıklarını taşıyan İngilizce ve Türkçe kitap ile akademik makaleler çalışmaya dâhil edilmiştir.

Araştırmada araştırma sorununa bağlı olarak liberalizmin öğretim ve eğitimin yönetimine etkilerinin sistematik incelenmesi amacıyla temel nitelikleri, eğitim alanına etki ve yansımaları öncelikle öğretimin programının yönetimi ve eğitimin yönetimine etkileri biçiminde iki ana alt boyuta ayrılmıştır. Daha sonra öğretimin programı bağlamında öğretim programı ögeleri olarak amaç, içerik-konu, öğretme ve öğrenme süreçleri ile ölçme değerlendirme boyutlarında incelenmesi planlanmıştır. Eğitimin yönetimi alt boyutu ise kendi içinde eğitim kurumlarının yönetimi ve ekonomik- politik boyut biçiminde iki alt boyuta ayrılmıştır. Bu kategorileştirmenin ardından liberalizmin eğitim kurumlarının yönetimi boyutlu etkilerini merkezden yönetim yerine yerelden yönetim, öğrenen ve velinin yönetime katılması, küreselleşme kuralsızlaştırma, toplam kalite yönetimi ile akademik ve yönetsel özerklik biçiminde beş alt başlıkta çalışılmıştır. Liberalizmin eğitime ekonomik-politik boyutlu etki ve yansımaları ise eğitimde özelleştirme, eğitim hizmetlerinden yararlananların eğitime mali katkısı, eğitimin piyasalaştırılması, eğitimin dışsallık argümanlarının zayıflatılması imajı biçiminde dört alt başlıkta incelenmiştir.

Araştırma probleminin detaylandırılması ve desenin oluşturulması ile ilgili bilgiler Tablo1'de verilmiştir: 
Tablo 1: Araştırma Sorusunun Detaylandırılması ve Desen Oluşturulması

\begin{tabular}{lll}
\hline Sorunun Boyutları & \multicolumn{1}{c}{ Tanım açıklama - soru } \\
\hline $\begin{array}{l}\text { Liberalizmin öğretim } \\
\text { boyutunda etkileri }\end{array}$ & programı & $\begin{array}{l}\text { Liberalizmin öğretim programının ögeleri boyutlarında (amaç, içerik- } \\
\text { konu, öğretme ve öğrenme süreçleri ve ölçme değerlendirme) eğitime } \\
\text { etkileri nasıldır? }\end{array}$ \\
\hline $\begin{array}{l}\text { Liberalizmin eğitim } \\
\text { boyutunda etkileri }\end{array}$ & yönetimi & $\begin{array}{l}\text { Liberalizmin eğitim yönetime etkileri nasıldır? } \\
\text { Merkezden yönetim yerine yerelden yönetim, } \\
\text { Öğrenen ve velinin yönetime katılması, } \\
\text { Küreselleşme kuralsızlaştırma, } \\
\text { Toplam kalite yönetimi ve Akademik ve yönetsel özerklik }\end{array}$ \\
\hline $\begin{array}{l}\text { Liberalizmin ekonomi-politik } \\
\text { boyutta eğitime etkileri }\end{array}$ & $\begin{array}{l}\text { Eğitimde özelleştirme, Eğitim hizmetlerine yararlananların eğitime } \\
\text { mali katkısı, Eğitimin piyasalaştırılması, Eğitimin } \\
\text { argümanlarıallık }\end{array}$ \\
\hline Sonuç yorum tartışma ve öneriler & Saptamalara dayalı olarak sonuç, tartışma ve öneriler \\
\hline
\end{tabular}

Tablo incelendiğinde liberalizmin eğitime etkilerinin dört boyutta temalaştı̆̆ görülebilir. Liberalizmin öğretim programı boyutunda etkileri; öğretim programının öğeleri olan amaç, içerik, öğrenme-öğretme süreci ve ölçme değerlendirme boyutlarında ele alınmaktadır. Eğitim yönetimi boyutunda; yerelden yönetim, yönetime katılım, kuralsızlaştırma ve akademik özgürlük alt boyutları araştırmaya konu edilmektedir. Özelleştirme, eğitime mali katkı, piyasalaştırma ve dışsallık argümanlarının zayıflatılması ekonomi-politik boyutu oluşturmaktadır. Sonuç, tartışma ve öneriler boyutunda ise saptamalara dayalı olarak sonuç, tartışma ve önerilere yer verilmektedir.

\section{BULGULAR}

Araştırmanın bulguları liberalizmin; öğretim programına etkileri, eğitim kurumlarının yönetimi boyutunda etkileri ve ekonomi-politik boyutlu etkiler bağlamında alt başlıklar halinde ele alınmaktadır.

\subsection{Liberalizmin Eğitime Öğretim Programı Boyutunda Etkileri}

Araştırmanın alt amacına dayalı olarak liberalizmin eğitime öğretim programı boyutunda etkileri ve ilişkili yorum Tablo 2'de verilmiştir (Tezcan, 2015; Kale, 2014):

Tablo 2: Liberalizmin Ĕ̈itime Öğretim Programı Boyutunda Etkileri

\begin{tabular}{|c|c|c|}
\hline & Etkiler ve Yansımalar & Yorum \\
\hline Amaçlar & $\begin{array}{l}\text { Özgür ve ekonomik birey - işe yararlılık, etkili, } \\
\text { verimli olma - bireycilik - piyasa ekonomisi } \\
\text { yönelimli amaçlar }\end{array}$ & $\begin{array}{l}\text { Özgür, üretken, yatırımcı vizyona sahip birey } \\
\text { yetiştirme - Demokratik davranımlı, eleştirel ve } \\
\text { analitik düşünen birey }\end{array}$ \\
\hline İçerik ve konu & $\begin{array}{l}\text { Demokrasi, özgürlükçülük, hukuk, ekonomik } \\
\text { verimlilik, piyasa ekonomisi odaklı konular }\end{array}$ & $\begin{array}{l}\text { Demokrasi ve yurttaşlik dersleri - işlevsel } \\
\text { felsefe sosyoloji dersleri - Çok kültürlülük - } \\
\text { Seçmeli din dersleri }\end{array}$ \\
\hline
\end{tabular}


Tablo 2 (Devam): Liberalizmin Eğitime Öğretim Programı Boyutunda Etkileri

\begin{tabular}{llll}
\hline $\begin{array}{l}\text { Öğretme } \\
\text { öğrenme süreci }\end{array}$ & ve & $\begin{array}{l}\text { Birey ve bireycilik merkeze alınması } \\
\text { Farklılaştırılmış öğretim - İşbirlikli öğrenme }- \\
\text { Yapılandırmacılık - Kapsayıcı eğitim ortamları }\end{array}$ & $\begin{array}{l}\text { Demokratik katılımlı eğitim - Öğrenci } \\
\text { merkezlilik - Çok kültürlü ortamlar - Kapsayıc1 } \\
\text { eğitim - Üretim süreciyle iç içeliğe dayalı } \\
\text { öğrenme süreçleri }\end{array}$ \\
\hline $\begin{array}{l}\text { Ölçme } \\
\text { değerlendirme }\end{array}$ & ve & $\begin{array}{l}\text { Bireysel hak ve özgürlüklerin bilincinde etkili, } \\
\text { verimli, bağımsız ve yaşama hazır bireyler hainle } \\
\text { gelip gelmedikleri ölçülmelidir. }\end{array}$ & $\begin{array}{l}\text { Objektif testler - İşevuruk ölçme değerlendirme } \\
- \text { Ölçme değerlendirme süreçlerine itiraz hak } \\
\text { arama }\end{array}$ \\
\hline
\end{tabular}

Tablo 2'de verilen bilgiler ile genel edinimlere bakıldığında şu bulgulara yer verilebilir. Öğretim programının yönetimi bağlamında eldeki bulgulara dayalı olarak şu görüşlere yer verilebilir: Öncelikle liberalizmin ekonomik-politik yönünün baskın olması eğitim yorumlarını farklılaştırmaktadır. $\mathrm{Bu}$ durum, liberalizmin eğitimle ilgili algı, bakış ve anlayışlarının farklı oluşunu doğurmaktadır. Buna bağlı olarak elde edilen görüşlerin liberallerin "pedagojik" bağlamda eğitime ilişkin "bütüncül ve asli" görüşlerinden çok sosyal, ekonomik ve politik duruşun eğitim alanına yansıması olarak görülebilir. $\mathrm{Bu}$ nedenle liberalizmin eğitime ilişkin görüşlerinin bir kısmı doğrudan liberalizmin açık manifestosu olamamaktadır. Ancak yüzyıllardır sosyoekonomik ve politik olarak yaygın uygulama alanı bulan bir anlayışın eğitim dünyasında önemli bir mirasının olduğu açıktır.

Çalışmanın ikinci alt amacı, liberalizmin bir toplumsal kurum olarak eğitimin yönetimine yönetim süreci, ekonomik ve politik boyutlarda etkilerinin neler olduğu ve toplumsal kurum olarak eğitimi nasıl etkilediği, yansımalarının nasıl olduğu biçiminde oluşturulmuştu. Bu bağlamda problem (a) eğitim kurumlarının yönetimi boyutlu etkiler, (b) eğitim kurumlarına ekonomik-politik boyutlu etkiler biçiminde iki alt grupta toplanmıştır.

\subsection{Liberalizmin Eğitim Kurumlarının Yönetimi Boyutlu Etki ve Yansımaları}

Liberalizmin eğitim kurumlarının yönetimi boyutlu etkilerini merkezden yönetim yerine yerelden yönetim, öğrenen ve velinin yönetime katılması, küreselleşme kuralsızlaştırma, toplam kalite yönetimi ve akademik ve yönetsel özerklik biçiminde beş alt başlıkta çalış1 lmıştır.

Liberalizmin eğitim kurumlarının yönetimi boyutlu etkileri ve ilgili yorumlar Tablo 3'te verilmiştir (Tezcan, 2015; Kale, 2014):

Tablo 3: Liberalizmin Eğitim Kurumlarının Yönetimi Boyutlu Etkileri ve Yorumlar

\begin{tabular}{|c|c|c|}
\hline & Etkiler Yansımalar & Yorum \\
\hline $\begin{array}{l}\text { Merkezden yönetim } \\
\text { yerine yerelden } \\
\text { yönetim }\end{array}$ & $\begin{array}{l}\text { Bütün şehir ve yerel yönetim yeni kamu } \\
\text { yönetimi düzenlemeleri }\end{array}$ & $\begin{array}{l}\text { Teorik olarak 'iyi' ancak uygulamalarda } \\
\text { merkezileşme eğilimi }\end{array}$ \\
\hline $\begin{array}{l}\text { Öğrenen ve velinin } \\
\text { yönetime katılması }\end{array}$ & $\begin{array}{l}\text { Okullarda öğrencilerin yönetime } \\
\text { katılmaları }- \text { Okul aile iş birliği } \\
\text { faaliyetleri ve kampüs uygulamaları }\end{array}$ & $\begin{array}{l}\text { Göreceli 'iyi’ uygulamalar - Oligarşik } \\
\text { grupların oluşma eğilimi }\end{array}$ \\
\hline $\begin{array}{l}\text { Küreselleşme } \\
\text { kuralsızlaştırma }\end{array}$ & $\begin{array}{l}\text { Sermaye, mal ve işgücünün serbest } \\
\text { dolaşımı - Çalışma koşulları ve üretim } \\
\text { süreçlerinde kuralsızlık }\end{array}$ & $\begin{array}{l}\text { Emeğin aleyhine sermaye sınıflarının } \\
\text { lehine işleyiş - Örgütsüzlük - Sarı } \\
\text { sendikacılık }\end{array}$ \\
\hline Toplam kalite yönetimi & $\begin{array}{l}\text { Okullarda toplam kalite yönetimi } \\
\text { uygulamaları }\end{array}$ & $\begin{array}{l}\text { Resmi kurumlarda teoride kalan - } \\
\text { Özel kurumlarda göreceli uygulama } \\
\text { olanağ1 }\end{array}$ \\
\hline $\begin{array}{l}\text { Akademik ve yönetsel } \\
\text { özerklik }\end{array}$ & $\begin{array}{l}\text { Akademik ve yönetsel özerklikler - } \\
\text { Düşünce ve inanç özgürlükleri - } \\
\text { Demokratikleşme, Katılımlı yönetim }\end{array}$ & $\begin{array}{l}\text { Teorik olarak demokratikleşme pratikte } \\
\text { hegemonik ilişki } \\
\text { Otoriter merkezden yönetim }\end{array}$ \\
\hline
\end{tabular}


Tablo 3'te verilen bilgi ile genel edinimlere bakıldığında şu bulgulara yer verilebilir. Liberalizmin eğitim kurumlarının yönetimi boyutlu etkilerinden biri merkezden yönetim yerine yerelden yönetim anlayışının egemen kılınmasıdır. Liberal görüşe göre okullar merkeziyetçi yönetim anlayışı ile sıkı bir yönetim algısı içinde boğulmaktadır. Okullar ve bütün kamu yönetiminin yerinden yönetim anlayışa dayalı olmalıdır (Tezcan, 2015). Okul yöneticilerinin merkezden atanması ve hatta programların merkezi otoriteye göre yapılması hem zorluk hem antidemokratiklik içerir. Yönetsel olarak özerklik ve yerinden yönetim esas alınmalıdır. Bu durum hem pazar ekonomisine hem de yönetsel demokrasiye uygundur.

Liberalizmin eğitim yönetimine bir başka etkisi ise demokratikleşme ile ilgilidir. Demokratikleşmenin bir sonucu olarak eğitimde demokratikleşme ve yönetime katılma öne çıkmaktadır. $\mathrm{Bu}$ bağlamda okullarda ögrenenin ve velinin yönetime katılması örnekleri görülmektedir. Liberalizmin özünde bulunan birey ve bireyin hakkı demokratikleşme ve yönetime katılmayla bireyin kendini göstermesi ve gerçekleştirmesine olanak sağlanmaktadır. Bu durum sınıf, okul ve giderek daha üst düzeylerde yönetime katılma eğilimleri olarak sıralanabilir. Ancak bu saptamaya yönelik özellikle politik, sosyalist ve sol kanattan yoğun bir eleştiri yapılmaktadır. Şöyle ki liberalizmin bu tavrının göstermelik "sanal" olduğu, özünde özellikle yirmi birinci yüzyıldaki uygulamaları ile liberalizm "neo" niteliği ile otoriter, totaliter rejimlere kaynaklık etmektedir (Birch, 2017).

Liberalizmin yirminci yüzyılın özellikle son çeyreği ile birlikte küreselleşme yoğunluk kazanmakta; dünya tek pazar olma eğilimi göstermektedir. Küreselleşme hem ekonomik hem de yönetsel boyutlarıyla dünyayı etkilemiştir. Ekonomik olarak ulusal sınır tanımayan yüksek rekabet egemenlik kurarken yönetsel düzeyde ise kuralsızlaştırma egemen olmaktadır (Arı, 2006). Birbirinden soyutlanmayan bu iki boyut ekonomide tekellerin lehine yönetsel alt yap1 oluşturmuş; iş görenler sendikasız, temel işçi haklarından yoksun çalıştırılmaya başlanmıştır. Bu durumun eğitim yönetimine yansımaları, değişik statülerde öğretmen ve hizmet iş göreni çalıştırılmasını doğurmuştur. Kadrolu, sözleşmeli, alt işveren (taşeron) çalıştırma biçimleri kimi örneklerdir (Akyiğit, 2011). Bu durumun üretim etmenlerinden emeğin aleyhine çalışmakta olduğu açıktır. Nitekim Türkiye'de özellikle özel okul ve eğitim kurumlarında çalışan öğretmen ve diğer eğitim işgörenlerinin özlük hakları son derece olumsuz ve kötü koşuldadır. Öğretmen adayları "Her koşulda çalışırım." durumundadır.

Liberalizmin günümüz eğitim yönetimine bir başka etkisi ise toplam kalite yönetimi anlayışıdır. Toplam kalite yönetimi örgütlerin yönetimine ekonomik, sosyal iç ve diş etmenler ile bütüncül bakılmasını amaçlar. Liberalizmin etkili ve verimli örgüt oluşturulması ile bireyin merkeze alınmasını içeren yönetime katılımının bir arada olabildiği bir yaklaşım olarak da değerlendirilebilir. Bu noktada eğitim kurumlarında özellikle 1990'ların ikinci yarısında toplam kalite yönetimi uygulamalarının yoğunlaştığı görülmektedir (Kiran, 2016). Genelde özel ve mal üreten kurumlara uygulama olanağı bulan toplam kalite yönetiminin eğitim kurumlarındaki kimi yansımaları şu biçimde özetlenebilir: Kalite çemberleri, sorun çözme odaklılık, sorunlara çok boyutlu bakış ve kuruma sistematik işleyişle bakış birlikte yönetim anlayışları ile bütüncül bir anlayış geliştirmiştir. Toplam kalite yönetimi anlayış ve uygulamalarına da işgörenlerin aleyhine çalıştı̆̆ı odaklı eleştirileri yapılmaktadır.

Liberalizmim eğitim yönetimine bir başka yansıması, akademik ve yönetsel özerkliktir. Liberaller eğitim politikalarında akademik özerkliğe, öğrenme ve öğretme özgürlüğüne özel bir anlam ve önem verirler. Öğretmenlerin öğretme, öğrencilerin öğrenme hakk1 vardır. Öğretmenler öğrenmeyi kolaylaştıran bir sınıf atmosferi yaratmakla görevlidir. Bu bakış özünde liberalizmin istenci olarak olumlu bir etki olarak nitelendirilir. Bununla birlikte karşıt görüş ise özellikle tek kutuplu dünya ile liberalizm eski "demokratik" ve "insancıl” özünü yitirmiş ve "neo" uygulamalar ile merkezci, akademik yönetsel özerklik karşıtı bir nitelik göstermeye başlamıştır (Slobodian, 2018). Akademik ve yönetsel 
özerklik teorik olarak savunulmasına karş1lık az gelişmiş ve gelişme sürecindeki ülkelerde yetersizlikler görülmektedir. Üçüncü dünya ülkeleri ya da merkez dışı ülkelerde gerek yükseköğretim kurumları gerekse bütün olarak eğitim sistemlerinin otoriterleşmesi ve merkezden yönetim örnekleri baskındır. Üniversitelerin bu bağlamda 'toplumsal sorunları çözümleyici ve deşifre edici' olması gerekirken merkez hegemonik bağımlılık ilişkisi içine sürüklenmektedirler (Önder, 2008).

\subsection{Liberalizmin Eğitime Ekonomik- Politik Boyutlu Etki ve Yansımaları}

Liberalizmin eğitime ekonomik-politik boyutlu etki ve yansımaları birbirinden ayrılması oldukça güç olan dört alt başlıkta toplanmıştır. Bu etki ve yansımaları eğitimde özelleştirme, eğitim hizmetlerinden yararlananların eğitime mali katkısı, eğitimin piyasalaştırılması, eğitimin dışsallık argümanlarının zayıflatılması imajı biçiminde belirlemek mümkündür.

Liberalizmin eğitime ekonomi-politik boyutlu etkileri ve ilişkili yorumlar Tablo 4'te verilmiştir (Tezcan, 2015; Kale, 2014):

Tablo 4: Liberalizmin Eğitime Ekonomi-politik Boyutlu Etkileri ve Yorumlar

\begin{tabular}{|c|c|c|}
\hline Boyutlar & Etkiler ve Yansımalar & Yorum \\
\hline \multirow[t]{2}{*}{ Eğitimde özelleştirme } & Okulların özel sektöre devri & Fırsat ve olanak eşitliği olumsuz \\
\hline & Nicel büyüme ve Nitel gelişim & $\begin{array}{l}\text { Sosyal hareketlilik alt sosyal katmanların } \\
\text { aleyhine işleyiş }\end{array}$ \\
\hline \multirow{2}{*}{$\begin{array}{l}\text { Eğitim hizn } \\
\text { yararlananların } \\
\text { mali katkısı }\end{array}$} & Devlete mali desteğin çoğalması & Alt gelir grupların aleyhine işleyen \\
\hline & $\begin{array}{l}\text { Eğitime ayrılan mali kaynakların } \\
\text { çeşitlenmesi }\end{array}$ & Kamuya gelir toplanan bir uygulama \\
\hline Eğitimin piyasalaştırılması & $\begin{array}{l}\text { Okulların ve eğitim hizmetinin ekonomik } \\
\text { bir mal gibi alınıp satılması, Rekabet }\end{array}$ & $\begin{array}{l}\text { Eğitimin sosyal faydasının azalması, } \\
\text { Sosyal katman sınıflar arası farklılıklar }\end{array}$ \\
\hline $\begin{array}{l}\text { Eğitimin dışsallık } \\
\text { argümanlarının } \\
\text { zayıflatılması imajı }\end{array}$ & $\begin{array}{l}\text { Eğitimin artık meslek için diploma ve } \\
\text { sertifika veren bir kurum algısı }\end{array}$ & $\begin{array}{l}\text { Eğitim sadece eğitimdir } \\
\text { Eğitilmiş olmak dışındaki getirilerde } \\
\text { azalma eğilimi }\end{array}$ \\
\hline
\end{tabular}

Tablo 4'te verilen bilgi ile genel edinimlere bakıldığında şu bulgulara yer verilebilir. Liberalizm makro düzeyde eğitime ekonomik etki ve yansıması eğitimde özelleştirmedir. Liberalizm özü gereği üretim sürecinin etkili ve verimli işlemesini esas alır. Bu açıdan eğitim hizmetlerinin hızlı ve nitelikli üretimi ve dağıtımını, kaynakların rasyonel kullanılmasını amaç edinir. Bu amaçla özellikle 1980'li y1llarla birlikte eğitim, sağlık, sosyal güvenlik gibi aslında sosyal devletin temel görevi olan alanlardan devletin geri çekilmesi esas alınmıştır. Kısaca eğitimde özelleştirme yoluyla devletin eğitim hizmetinin verilmesi ve finans edilmesini adım adım özel sektöre bırakmaya başlamıştır (Green, 2005). Bireyler, emek gücünün yeniden üretimi sürecinde özelleștirme, yeni işletmecilik, toplam kalite yönetimi, esnek çalışma koşulları, çağa uygun becerileri edindirme gibi farklı ad ve yöntemler aracıllğı ile neoliberalizmin bir parçası haline getirilmiştir (Yılmaz ve Sarpkaya, 2016). Bu durum genel olarak bir olumlu bir de olumsuz sonuç doğurmuştur. Özelleştirme bir taraftan eğitim kurumlarının nicel 
büyümesini ve niteliksel gelişimi sağlamış, okullarda "kalite" artmıştır. Ancak kamu ve özel okullar arasında nitelik farklılığı ile firsat ve olanak eşitliği açılarından eleştirilmiştir. Özelleştirme ile eğitim bir bakıma "Paran kadar oku." noktasına kadar düşürülmüştür. Ayrıca ülkelerin sosyal dayanışma ve eğitimin alt sosyal katmanların sosyal hareketliliğine olumlu katkıları zayıflamıştır, denilebilir.

Liberalizmin eğitime bir başka yansıması ise eğitim hizmetlerinden yararlananların eğitime mali katkısı uygulamalarıdır. Özellikle Sovyetlerde reel sosyalizmin yıkılmasının ardından kapitalist ülkelerde eğitim, sağlık ve sosyal güvenlik gibi sosyal devlete özgü işlere ayrılan mali pay küçültülmüş ve giderek azaltılarak en az seviyeye çekilmeye çalışılmıştır. Eğitime devlet desteğinin azaltılması amacıyla eğitimden yararlananların bir hizmet almaları nedeniyle katkı vermeleri uygulamalarına bir geçiş yapılmış ve giderek bu durum yaygınlaştırılmaya çalışılmıştır.

Liberalizmin eğitime bir başka etkisi ise ĕgitimin piyasalaştırılması çalışmalarıdır. Eğitim özellikle 1980'lerdn sonra giderek özel mal gibi piyasa koşullarında bir ekonomik mal konumuna düşürülmüştür. Eğitim alınıp satılan bir meta olarak kamusal ve sosyal yönü ötelenmiş ve yeniden tanımlanmıştır. Rekabetçi, piyasacı ve tüketim malı olarak piyasanın emrine girmiştir. Artık eğitim sosyal hareketliliği alt gelir gruplarının da kısmi lehine etkileyen bir değişken olmaktan öte farklılıklar arasında arayı açan bir nitelik taşımaya başlamıştır (Yılmaz ve Sarpkaya, 2016).

Eğitimin dışsallık argümanlarının zayıflatılması imajı: Devletin eğitim faaliyetlerinde bulunmasını destekleyen görüşleri kabaca dört grupta toplanır. Bunlar dışsallık, bilgi, sermaye piyasası başarısızlıkları ve eşitlikçiliktir. Eğitim eski dönemlerde kamusal mal olarak devlet tarafından sunulması alt gelir ve olanaksız kesimlerin göreceli lehine işlemiş olduğu bir gerçekliktir. Ancak liberalizmin yeni uygulamaları ile piyasacılık ile özelleştirme sosyal sistemlerde onulmaz yaralar açmış eşitsizlikleri daha derin olarak yeniden üretmiştir (Friedman, 2008).

Liberalizmin sosyoekonomik boyutta eğitim yönetimine etkileri konusunda şu genel yorum yapılabilir: Liberalizmin kapitalizmden ayrı düşünülmesi mümkün değildir. Tarihsel gelişim sürecinde liberal kapitalist sistem erken kapitalizm sonrası sanayi devriminin üretim ve tüketim olanaklarını arttırmıştır. Üretimde nicel artış, nitel değişim refah düzeyini yükseltmiş; daha iyi bir yaşam olanağı sağlamıştır. Ancak liberal kapitalist sistemin tekelleşme, eşitsiz gelişim, firsat ve olanak eşitsizlikleri gibi olumsuzluklar yarattığı açıktır (Çelik ve Dağ, 2018). Bu noktada gerek pozitivist gerekse materyalist yaklaşımlar liberalizmin erken dönemde tarihte büyüme, sosyal değişim, refah ve aydınlanma gibi önemli olumlu gelişimlerin oluşumuna kaynaklık ettiğini savunmaktadır. Ancak tarihsel gelişim içinde özellikle materyalistler tekelci kapitalizm yani emperyalizm ve neoliberal dönemle birlikte liberal kapitalist sistemin olumsuz bir evrim geçirdiği savındadır (İnsel, 2015). Çalışmada eğitime yönelik olumlu etki ve yansımaların erken kapitalizm sonrasına, olumsuzlukların ise tekelci döneme denk geldiği söylenebilir.

\section{TARTIŞMA ve SONUÇ}

Liberalizmin öğretim programı ve eğitim kurumlarının yönetimine etkilerinin pedagojik olmaktan çok sosyal, ekonomik, politik odaklı olduğu ve pedagojik boyutun bu odaklılığa göre şekillendiği söylenebilir. Bu durumun ana nedeni liberalizmin ağırlıklı olarak sosyoekonomik, politik merkezli yaklaşım olmasıdır. Nitekim gerek öğretim gerekse kurum yönetim boyutlu etki ve yansımalar ağırlıklı olarak özgürlük, demokrasi, katılım, piyasa, özelleştirme, devletin eğitim alanından çekilmesi gibi sosyal, ekonomik ve politik boyutlu etki ve sonuçlardır. 
Liberalizmin eğitim kurumlarının yönetimine mikro boyutlu etkileri genelde yerinden yönetim ve demokratik katılım boyutludur. Öğretmen, öğrenci ve velilerin okul yönetimine katılımı demokratikleşme açısından önemli gelişmeler olmakla birlikte işlevsellik ve uygulanabilirlik açısından kimi karşıt farklı görüşler de bulunmaktadır. Akademik özgürlüğün eğitimin "kasıtlı ve istendik" amaçlılığı ile ne derece bağdaşacağı ayrı bir tartışma konusudur.

Liberalizmin eğitim kurumlarının yönetimine makro boyutlu etkileri ağırlıklı olarak yerinden yönetim ya da yaygın ifadeyle kamunun yönetiminin yerinden yönetim anlayışla yönetilmesidir. $\mathrm{Bu}$ bağlamda özellikle farklı kültürlerden oluşan "milli” yapıların bölünme ve ayrışmaya neden olacağı kaygı ve kuşkuları bulunmaktadır. Bu durumun politik pratikte çok tartışmalı olduğu açıktır.

Liberalizmin eğitim kurumlarının yönetimi boyutlu etki ve yansımalarına nasıl bakılacağı önemli politik tartışmalara neden olmaktadır. Örneğin özelleştirme, eğitim hizmetlerinden yararlananların mali katkısı, eğitime devlet desteğinin azaltılması, eğitimin piyasalaştırılması ile eğitimin dışsallık etkilerinin kime göre ve nereden bakıldı ğına göre değişen yorumlara neden olmaktadır. Bu bağlamda oluşan duruma genel olarak çatışmacı sosyalist ya da politik "sol" bağlamlı bakan yaklaşımlar bu etkilerin "olumsuz" etkiler olduğunu savunmaktadır. Bu etkiler sonucu sosyal katmanlar arasındaki sosyal ve ekonomik farklılıklar artmakta, makas açılmakta ve eğitimin sosyal hareketlilik işlevi alt gelir gruplarının aleyhine işlemektedir. Buna karşılık liberal, 'sağ' ya da işlevselci, yapısalcı yaklaşımlar özelleştirme ve diğer etkilerin eğitim süreç ve işleyişlerini "olumlu” etkilediği görüşündedir. Bu noktada bu yaklaşımlara göre özelleştirme ve benzer diğer liberal politika ve uygulamalarla eğitimde etkililik, verimlilik ve nitelik artmaktadır.

Liberalizmin öğretim programının yönetimi boyutlu yansımaları genel olarak demokratikleşme ve bireyin merkeze alınması boyutlu yansımalar olarak görülebilir. Amaç, içerik, öğretim ve ölçme değerlendirme süreçleriyle eğitime birey amaçlı bakılması öne çıkarılmaktadır. Bir bakıma devlet otorite için değil, birey için eğitim anlayışııın baskın olması amaçlanmaktadır. Ancak pratikte sosyal, ekonomik ve politik işleyiş̧in buna ne derece olanak vereceği tartışmalıdır.

\section{5. ÖNERILLER}

$\mathrm{Bu}$ çalışmada liberalizmin eğitim alanına etkileri öğretim programı ve kurumsal yönetimi boyutlu ve alan taramasına dayalı çalışılmışır. Liberalizmin eğitim alanına etkileri alan uzmanlarına sorularak nicel ve nitel araştırmalar yapılabilir. Ayrıca liberalizmin etkileri öğretmen, öğrenci ve veliler örnekleme alınarak farklı araştırmalar yapılabilir.

Liberalizmin etkileri ile diğer sosyoekonomik, politik yaklaşımların etkilerini karşılaştıran araştırmalar yapılabilir. Bu bağlamda örneğin liberalizmin ve materyalizmin eğitime etkilerini karşılaştıran araştırmalar önerilebilir.

Liberalizmin program, yönetim ve sosyoekonomik olarak eğitime etkilerinin pratikte hangi sonuçlar yarattığı araştırma konusu yapılabilir. Özelleştirme, toplam kalite, alt işveren uygulamaların pratikte sosyal, ekonomik ve politik etkileri ile farklı sosyal katmanların bu uygulamalara yönelik görüş ve tutumlarını konu edinen araştırmalar yapılabilir.

Çalışma ve alanyazında sıklıkla vurgulanan liberalizmin olumlu olumsuz etkilerinin uygulamada nasıl olduğunu belirlemeye yönelik araştırmalar yapılabilir. Bu bağlamda örneğin liberal politik ve uygulamaların sosyal hareketliliğe, eğitimden yararlanmaya, sosyal eşitsizliklere, fırsat ve olanak eşitliğine etkileri araştırma konusu yapılabilir. 


\section{KAYNAKLAR}

Ağaoğulları, M. ve Köker L. (1991). Tanrı devletinden kral devletine. Ankara: İmge.

Aktan, C. C. (1995). Klasik liberalizm, neo liberalizm ve libertarianizm. Erişim adresi: https://www.researchgate.net/publication/318701036_Klasik_Liberalizm_Neo_Liberalizm_ve_Libertarian izm.

Aktel, M. (2001). Küreselleşmenin süreci ve etki alanları. Süleyman Demirel Üniversitesi İktisadi ve İdari Bilimler Fakültesi, 6 (2), 193-202.

Akyiğit, E. (2011). Işs ve sosyal güvenlik hukukunda alt işverenlik (taşeronluk ilişkisi). İstanbul: Seçkin.

Arı, F. A. (2006). Küreselleşme ve kuralsızlaştırma. Çalışma ve Toplum: Ekonomi ve Hukuk Dergisi, (3), 23-29.

Arı, T. ve Tan, R. (2018). Liberalizmde siyasal özgürlük ve ekonomik özgürlük ilişkisi. Erişim adresi: https:// www.academia.edu.

Başdemir, H. Y. (2007). Liberalizmin ahlaki temelleri. Yayınlanmamış Doktora Tezi. Ankara: Ankara Üniversitesi, Sosyal Bilimler Enstitüsü.

Birch, K. (2017). A research agenda for neoliberalism. Glos: Edward Elgar Publishing Ltd.

Boratav, K. (2016, 3 Haziran). Bir neoliberalizm eleştirisi. Erişim adresi: https://www.birgun.net/haber/birneoliberalizm-elestirisi-114528.

Burns N. ve Grove, S. K. (2011). Understanding nursing research. (5th Edition). New York: Elsevier Inc.

Cau, R. (2009). Liberalism: A political philoshopy. Erişim adresi: https:/www.mannkal.org/downloads/scholars/ liberalism.pdf

Cevizci, A. (2019). Felsefeye giriş. (7. Bask1). İstanbul: Say Kitap.

Çelik, F. ve Usta S. (2011). Liberal düşünür Hayek'in özgürlük düşüncesi ve bu perspektiften yerel yönetimlere bakışı. Süleyman Demirel Üniversitesi Sosyal Bilimler Enstitüsü Dergisi, (14), 89-104.

Çelik, M. ve Dă̆, M. (2018). Kapitalist iktisadi düşüncenin geçirdiği dönüşümler üzerine bir değerlendirme. Bitlis Eren Üniversitesi İktisadi ve İdari Bilimler Fakültesi Akademik İzü̈şüm Dergisi, 2(3), 50-70. Erişim adresi: https://dergipark.org.tr/en/download/article-file/346558.

Çetin, H. (2001). Liberalizmin temel ilkeleri. Cumhuriyet Üniversitesi İktisadi ve İdari Bilimler Dergisi, 2, (1), 219-237.

Erdoğan, İ. (2001). Ulusal kalkınma ve eğitim ilişkisi. Liberal Düşünce, 6 (21), 34-39.

Erdoğan, M. (2003) Anayasal demokrasi. Ankara: Siyasal.

Erdoğan, M. (2018). Liberalizm ve Türkiye'de liberal eğilimler. Erişim adresi: http://www.liberal.org.tr/sayfa/\%20liberalizm-ve-turkiyede-liberal-egilimler-mustafa-erdogan,344.php.

Galvan, J. (2006). Writing literature reviews: a guide for students of the behavioral sciences (3rd Edition). Glendale: CA: Pyrczak.

Göze, A. (2016). Siyasal düşünceler ve yönetimler. (16. Basım). İstanbul: Beta.

Green, C. J. (2005). The privatization of state education: public partners, private dealings. New York. Routledge.

Gümüş, A. (2008). Bir ayrıştırma mekanizması olarak okul ve üniversite. S. Akyol, M. K. Çoşkun, Z. Yılmaz, M. B. Aydın ve R. Altunpolat (Ed.), Dönüştürülen üniversiteler ve eğitim sistemimiz içinde (s.439-481). Ankara: Eğitim Sen Yayınları.

Hayek, F. A. (1995). Kanun yasama faaliyeti ve özgürlük (sosyal adalet serabı). (M. Erdoğan, Çev.). Ankara: Türkiye İş Bankası Kültür.

Holcombe, R. G. (1994). The economic foundation of government. New York: New York University.

İnsel, A. (2015). Neo-liberalizm: Hegemonyanın yeni dili. (4. Bask1). İstanbul: Birikim.

Kale, N. (2014). Felsefiyat. (2. Baskı). Ankara: Pegem Akademi.

Kaşık, S. (2015). Bilimsel araştırma ve makale türleri. Erişim adresi: https://www.sametkasik. com.tr /bilimselarastirma-makale-turleri.html 
Kiran, D. R. (2016). Total quality management: key concepts and case studies. New York: BSP

Merriam, S. (1988). Case study research in education: a qualitative approach. San Fransisco: CAJossey -Bass.

Önder, İ. (2008). Üniversite özerkliği bilimsel özerklik ve demokrasi. S. Akyol, M. K.Çoşkun, Z. Yılmaz, M. B. Aydın ve R. Altunpolat (Ed.), Dönüştürülen üniversiteler ve eğitim sistemimiz içinde (s.11-26). Ankara: Eğitim Sen.

Öztekin, A. (2018). Siyaset bilimine giriş. (11. Bask1). Ankara: Siyasal Kitabevi.

Rallis, H. M. (2018,19 Nisan). Guidelines for writing a literature review. Erișim adresi: https://www.d.umn.edu/ hrallis/guides/researching/litreview.html.

Ralph, R. (2011). Klasik liberalizm nedir? (Çev. A. Yayla). Erişim adresi: http://www.libertedownload.com/ LD/arsiv/ 64/04-ralph-raico-klasik-liberalizm-nedir.pdf.

Sambur, B. (2011). Din özgürlüğü, çoğulculuk ve liberal demokrasi. Liberal Düşünce Dergisi, 16 (63), 7-14

Slobodian, Q. (2018). Globalists: the end of empire and the birth of neoliberalism. Cambridge: Harvard University Press.

Şahin, B. (t.y.). Liberal demokrasinin temelleri. Erişim adresi: http://www.liberal.org.tr/sayfa/liberaldemokrasinin-temelleri-bican-sahin,188.php.

Tanilli, S. (2007). Devlet ve demokrasi. Ankara: Alkım Yayınları.

Tezcan, M. (2015). Sosyolojiye giriș. (8. Baskı). Ankara: Anı Yayıncılık.

Torraco, R, J. (2005). Writing integrative literature reviews: guidelines and examples. Human Resource Development Review, 4, (3), 356-367.

Turancı, E. ve Bulut, S. (2016). Neo-liberalizm ve sağlık hizmetlerinin dönüşümü: Özel sağlık sektörünün iletişim politikaları üzerine bir analiz. Illetişim Kuram ve Araştırma Dergisi, (43), 40-63.

Türk, H. B. (2003). İdeoloji. M. Türköne (Ed.), Siyaset içinde (s.105-145) Ankara: Lotus.

Uzunyayla, F. ve Ercan, F. (2008). Türkiye'de eğitim sistemine yönelik yeni talepler ve yeni aktörlere sınıfsal bir bakış. S. Akyol, M. K. Çoşkun, Z. Yılmaz, M. B. Aydın ve R. Altunpolat (Ed.), Dönüştürülen üniversiteler ve ĕgitim sistemimiz içinde (s.125-145). Ankara: Ĕgitim Sen.

Yayla, A. (2008). Liberalizm. (6. Bask1.). İstanbul: Liberte.

Yeldan, E. (2009). Kapitalizmin yeniden finansallaşması ve 2007/2008 krizi: Türkiye krizin neresinde? Çalışma ve Toplum, (1), 11-28.

Yıldırım, A. ve Şimşek, H. (2018). Sosyal bilimlerde nitel araştırma yöntemleri. (11. Baskı). Ankara: Seçkin Yayınc1lik.

Yılmaz, T. ve Sarpkaya, R. (2016). Eğitim ekonomisi eleştirel bir yaklaşım. Ankara: Anı.

Yolcu, H. (2010). Neo-liberalizm ve eğitim. Bilim ve Gelecek, 71. Erişim adresi: https://bilimvegelecek.com.tr/index.php/2010/01/01/neo-liberalizm-ve-egitim-politikasi/. 


\section{EXTENDED ABSTRACT}

Liberalism, unlike most philosophies, has been influential in society for years with its social, economic and political aspects. Liberalism is an approach based on free market economy, individual freedom, democracy, freedom of investment, religion, conscience, thought and organization.

Liberalism is defined as the ideology of the new bourgeoisie, which seeks equality before the law with the clergy, aristocratic class, since it does not have many economic problems. Liberalism is in the understanding of "blind state" with the understanding of liberal state and of equal distance to all citizens. The point of departure of the state is the individual and the only real value is the individual. The individual is before society and the state. The individual is placed at the heart of the society and centered for the formation of the social order. Society should give freedom to the individual as much as possible in order to realize their full potential. Freedom, independence of mind and will is essential. The basic characteristics of liberalism can be summarized as individualism, freedom, wisdom, equality, tolerance, consent, limited state and government.

The main purpose of this study is to identify and discuss the effects of liberalism on the management of education and training. Based on the main purpose, the effects of liberalism in the dimensions of purpose, content-subject, teaching and learning processes, and assessment and evaluation, which are components of education curriculum, and how it affects the curriculum, as well as the effects and reflections on the management of education as a social institution in institutional management and economic-political dimensions have been investigated.

Method: The study is a literature review based on integrated and focused literature review. In the study, the problem of liberalism and its effects on education, analysis, synthesis and results are critically evaluated and suggestions are included.

Design: In this study, in order to systematically examine the effects of liberalism on the management of teaching and education, depending on the research problem, its basic qualities, its effects and reflections on the field of education are divided into two main sub-dimensions: the management of the teaching program and the effects of education. Then, in the context of the management of the teaching program, it is planned to examine the curriculum elements in the dimensions of purpose, content-subject, teaching and learning processes and assessment and evaluation. The education administration is divided into two sub-dimensions: the management of educational institutions and the economic-political dimension. Following this categorization, the effects of liberalism on the management of educational institutions have been studied under five sub-headings: local administration instead of centralized management, participation of learner and parents in management, globalization deregulation, total quality management, and academic and administrative autonomy. The effects and reflections of liberalism on education in economic-political dimensions are examined under four sub-headings: privatization in education, financial contribution of those who benefit from educational services, marketization of education, and the image of weakening the externality arguments of education.

According to liberalism, the purpose of education systems is to raise a free and economic individual.

Due to the liberalism's principles of advocacy of freedom and democracy, it is essential for individuals to have free thought. In addition, the adoption of democratic principles and the acquisition of democratic behavior are among the main objectives. Since liberalism is basically based on capitalist production and market economy, raising effective and productive individuals stands out as another goal. According to liberalism, the aim of education systems should be to educate the "free and economic"

Anadolu Üniversitesi Ĕ̆itim Fakültesi Dergisi (AUJEF), 5(3), 246-263 
individual. The following effects are seen in the context of content: Inclusion of democratic and libertarian issues in schools is dominant with the effect of political liberalism. In terms of liberalism, libertarianism and versatility prevail in the content of the programs. Liberalism advocates inclusion of course and program contents that will enable the individual to be versatile, free, effective and productive. Relativity and appropriateness must be integrated in the teaching and learning processes.

In the teaching and learning processes of liberalism's educational understanding, relativity and appropriateness are dominant. Liberalism has the freedom to find appropriate methods and techniques according to the understanding of "usefulness, effectiveness, efficiency and individualism" as the criteria of accuracy. In this context, differentiated teaching, collaborative learning and constructivism are approaches that are relatively suitable for liberal understanding for some of its applications and purposes. As for evaluation, it should be assessed that whether or not the individual is effective, efficient, independent and prepared for life and has the awareness of individual rights and freedoms.

The effects of liberalism on the management of educational institutions are determined as local instead of centralized management, participation of learners and parents in management, globalization, deregulation, total quality management, and academic and administrative autonomy.

The effects and reflections of liberalism on education in terms of economy and politics can be summarized as privatization education services, the financial contribution of the beneficiaries to the education, marketization of education and the image of undermining the externality arguments of education.

For this purpose, it aims at the fast and qualified production and distribution of educational services and the rational use of resources. For this purpose, especially in the 1980s, the withdrawal of the state from areas such as education, health, social security, which are actually the main duty of the social state, was taken as a basis. Through privatization in education, the state began to leave the provision and financing of education services to the private sector.

Another reflection of liberalism on education is the marketization practices of those who benefit from education services and contribute financially to the education. Especially after the collapse of real socialism in the Soviets, the financial share allocated to social-state jobs such as education, health and social security in capitalist countries has been decreased and it has been tried to be minimized by decreasing gradually. With private school courses and other applications, education has been transformed into a commercial product that is purchased and sold in the market. Thus, it is seen that the effect of positive externality and usefulness of education for lower income groups in society in general is gradually weakening.

The following general interpretation can be made about the effects of liberalism on educational administration at the socioeconomic level: It is not possible to consider liberalism separately from capitalism. In the historical development process, the liberal capitalist system increased the production and consumption possibilities of the early post-capitalist industrial revolution. Quantitative increase in production and qualitative change increased the welfare level; provided a better life opportunity. However, it is seen that the liberal capitalist system creates negativities such as monopolization, unequal development, inequality of opportunity and possibility. In the historical development, especially materialists argue that the liberal capitalist system has undergone a negative evolution with monopoly capitalism, that is, imperialism and the neoliberal period. In the study, it is seen that positive effects and reflections on education coincide with post early-capitalism, and negativities coincide with the monopoly period. 
Recommendations: Quantitative and qualitative studies can be conducted by asking experts in the field the effects of liberalism on education. Studies comparing the effects of liberalism with the effects of other socio-economic political approaches can be performed. 